\section{International Scientific Journal Theoretical \& Applied Science}

p-ISSN: 2308-4944 (print) e-ISSN: 2409-0085 (online)

Year: $2018 \quad$ Issue: 02 Volume: 58

Published: $12.02 .2018 \quad \underline{\text { http://T-Science.org }}$
Hasan A. Mammadov

Department of World Economy and Management, Nakhchivan State University, AZ 7000, Nakhchivan Uneversity Campus, Nakhchivan, Azerbaijan Respublic

hasan_1961@mail.ru

SECTION 31. Economic research, finance, innovation, risk management.

\title{
CLASSIFICATION OF INFRASTRUCTURES
}

Abstract: The article focuses on the classification of infrastructure. The essence, content and functions of infrastructure are explained. It is shown that the views of world scientists about the classification, essence, content and significance of infrastructures with different functional functioning have never been unambiguous. A group of academics describe them as the production technologies, the production and non-production activities of the population, the interaction of buildings, structures, communications and terrain elements that provide normal development of recycling, while other group economists say that only infrastructure for industrial and coal production industries and so on.

In the article, the infrastructure is not only a material production but also a set of areas that serve social, market, ecological, international and military spheres. Here is a complete classification of infrastructures, showing each area's infrastructure and their specific boundaries. It should be noted that in order to ensure the sustainable development of the economy, it is important to ensure that all infrastructures are integrated in a comprehensive way.

Key words: infrastructure, classification, ecology, market, social, production, manufacturing technology, communication.

Language: English

Citation: Mammadov HA (2018) CLASSIFİCATION OF İNFRASTRUCTURES. ISJ Theoretical \& Applied Science, 02 (58): 35-39.

Soi: http://s-o-i.org/1.1/TAS-02-58-10 Doi: crossef https://dx.doi.org/10.15863/TAS.2018.02.58.10

\section{Introduction}

The concept of "infrastructure" is Latin origin. It expresses the combination of infra- "lower " and structure - "accommodation". For the first time, at the beginning of the twentieth century, A. Marshall used the term "infrastructure" to refer to US military facilities and buildings in the 40's. At present, the "infrastructure" has been widely used in the lexis as an economic terminology.

Research has shown that the views of world scientists on the classification, essence, content and significance of infrastructures with different functional functioning have never been unambiguous.

A group of scholars describe the nature and content of infrastructure in regional economics as describing them as interconnections between building technology, building, construction, communication and terrain elements that produce production, production and non-production activities, and normal development of recycling (1, p.280 281).

\section{Different approaches to infrastructure}

Other group economists consider infrastructure only as an aggregate of industries that serve the industry and the production of cobblestones, and when classifying it, they indicate that roads and their canals, canals, harbors, bridges, warehouses, energy farms, railways, communications, water supply, health and education, primary and secondary education (2).

Some economists regard infrastructure and services as roads, warehouses, transportation, communal, household services and social areas as well as areas and services that meet the needs and needs of the population.

V.V.Vlasov, unlike other researchers, has attempted to show the boundaries of the areas in which they belong, by combining infrastructure with relatively broader classifications (production, social, institutional and environmental infrastructures) (3, p.4). However, if we take into consideration the newly created, formed and existing infrastructure that meets the modern level of civilization and economy, 
we can see the deficiency of this classification as well

In our opinion, unlike this classification, infrastructure is functioning in all spheres and spheres that cover them throughout life activities in a broader sense.

In our country, research works have been conducted recently to investigate infrastructure, textbooks, textbooks and monographs have been written, and the laic researchers have not turned the theoretical and conceptual problems of infrastructures into a complete, complete research object. Professor T.Valiyev was the first and longterm researcher of this field in Azerbaijan. He studied the infrastructure in his economic theories published in various years, as well as in monographs he wrote in various years. He pointed out that the infrastructural approach is related to its material production areas and, generally, to the social production and at the same time the social services, as well as the differentiated activities of the infrastructure in the socio-economic status of the country, in other words, $(4, \mathrm{p} .14)$.

The economist scientist $\mathrm{T}$. Valiyev classified Infrastructures as: production, social, communal, and market infrastructure, which develops theoretical issues in accordance with the market economy of socio-economic infrastructure in its essence, classification and significance. This infrastructure has been called a large, large-scale classification of infrastructure, since these infrastructures themselves are also directly indivisible and sometimes thirdparty subgroups.

Economists M.M.Mahmudov and I.M. Mahmudova, summarizing their findings at the end of the headline "Infrastructure Understanding" at the "Regulation of Socio-Economic Development of Regions" published in 2011, have concluded that they have been able to produce infrastructure and infrastructure, can be divided into social infrastructure "(1, p.281).

Doctor of Economic Sciences, Professor G.P. Juravlyov, in the "Economic Theory, Microeconomics-1,2" textbook published in 2010 the authors distinguished the production, social and market infrastructure while classifying the collective infrastructure. They have not yet commented on other existing infrastructures, but have also shown wholesale trade as an integral part of the production infrastructure (5, p.181-183). A group of experts estimate infrastructure as a set of service areas to improve the productivity of the production process, or a set of service areas to improve the living conditions of the population, while a group of experts consider the unit as a set of complex areas aimed at normal functioning of the national economy (5, p.180 -181). The list of approaches to the classification of infrastructures can be increased. However, most researchers have failed to properly evaluate the functionality of the infrastructure, their substance and content.

Infrastructures are specialized areas that cover and broaden more broadly, scientifically and theoretically, characterized by the division of operations and other leading areas. Talking about infrastructure, not just the fields that support material production, but also the range of areas that serve social, market, ecological, international, and military must be taken into account.

But even today, various ideas about the essence, content and classification of infrastructure in economic literature continue.

It is clear from the research and research that we have not formulated a single hedge against the theoretical aspects of infrastructures so far by both Azerbaijan and foreign economists.

In the context of modern economic development, we can say that the concept of infrastructure is deeply ingrained. Generally speaking, the infrastructure should mean that the totality of areas that create favorable conditions for the normal functioning of the economy as well as its separate units should be understood.

One of the key elements of infrastructure is the provision of public services to meet all the phases of public recycling: focusing on the formation of mutual relations between production, distribution, exchange and consumption

This is because the infrastructure is considered to be a research object of economic theory.

By the way, when you say infrastructure, the essence of the economic system, its internal structure, comes from the functions it performs in accordance with its essence.

\section{Modern classification of infrastructures}

In our view, infrastructure in the market economy should cover a range of sectors of the economy, which interact with each other, from different market segments - production, social, market, international, institutional and ecological systems, as well as the normal functioning of the Armed Forces.

Considering the impact of the national economy on its sustainable development, its functional nature, content and content, the specific boundaries, and the separation of individual infrastructures, which are not included in any economic research, are as follows: 
Infrastructure Areas considering the impact of the national economy on its sustainable development, etc.

\begin{tabular}{|c|c|c|}
\hline S.№ & Infrastructure Areas & Supported Areas \\
\hline 1. & Market infrastructure & $\begin{array}{l}\text { Commodity markets: - Food and } \\
\text { wholesale and retail facilities, domestic service market; transport } \\
\text { market; utility market; housing markets; non-production buildings } \\
\text { and facilities; fairs, auctions;Labor market: labor markets;Financial } \\
\text { market: - capital market; investment market; credit market; Securities } \\
\text { market.Exchanges: - stock and stock exchanges, Rental and leasing } \\
\text { services, etc. }\end{array}$ \\
\hline 2. & Social infrastructure & $\begin{array}{l}\text { Facilities and facilities belonging to them, objects of social and } \\
\text { cultural purpose, all structures of housing and communal services, } \\
\text { organizations and enterprises of health care system, enterprises and } \\
\text { organizations involved in education and upbringing of children up to } \\
\text { school age, kindergartens, tourist organizations, hotels, sports and } \\
\text { health facilities, passenger transport, communication services (serving } \\
\text { the population,, legal counseling services for the population, notaries, } \\
\text { etc., created for the effective leisure and leisure of the population. }\end{array}$ \\
\hline 3. & Production infrastructure & $\begin{array}{l}\text { small, incomplete production areas, power transmission lines, fue } \\
\text { tanks, etc., all kinds of transportation, water, land and air transport } \\
\text { production-serving communications, water supply, sewage systems. } \\
\text { storage facilities, etc. }\end{array}$ \\
\hline 4. & Environmental Infrastructure & $\begin{array}{l}\text { Water treatment plants, smoke removal facilities and refineries, river, } \\
\text { sea and ocean wastewater treatment plants, waste disposal facilities; } \\
\text { alternative energy sources: - sunset, bioenergy generating units, wind } \\
\text { and water power plants, etc. }\end{array}$ \\
\hline 5. & International Infrastructure & $\begin{array}{l}\text { International Transportation, International Transportation (Air, Water, } \\
\text { Railway and Highway), international air and sea ports, international } \\
\text { stock exchanges, trade and market subjects, international information } \\
\text { and communications systems and facilities, etc. }\end{array}$ \\
\hline 6. & Institutional Infrastructure & $\begin{array}{l}\text { Customs, tax, financial systems, advertising agencies, auditing } \\
\text { organizations, information bureaus, advertising agencies, engineering } \\
\text { services, etc. }\end{array}$ \\
\hline 7. & Military infrastructure & $\begin{array}{l}\text { military bases, military industrial and educational institutions, } \\
\text { stationary buildings, armored vehicles, communications and } \\
\text { information systems, combat techniques and mechanisms that ensure } \\
\text { the deployment of armed forces and combat operations. }\end{array}$ \\
\hline
\end{tabular}

Note: The table was compiled by the author in accordance with the new classification of infrastructure.

\section{them}

\section{Infrastructure areas and areas covered by}

Market infrastructure. The formation of a market economy in Azerbaijan has led to the transformation of ideas and ideas into infrastructures into a substantial market infrastructure. Market infrastructure consists of a set of activities that ensure the effectiveness of functional activities of economic entities and facilities in the market economy. In other words, market infrastructure is a set of complex areas that embody the functional activities of national economic units that ensure normal functioning of the market and its development. It is the integrity of various institutions and organizations that serve the activities of different sectors of the economy.

Social infrastructure. A set of areas that directly and indirectly participates in providing people with normal living activities is an integral part of the national economy called social infrastructure. In short, social infrastructure is understood as a set of areas that can help improve the social status of people. In the modern era of civilization, the role of social infrastructure has increased, the scope of activities has expanded, and the quality of services has increased.

The importance of social infrastructure in the national economy is that they affect the re-generation 
of labor resources, which are the main resources of the economy. Social infrastructure is a set of industries and businesses that help ensure the standard of living of the population.

Production infrastructure. Industrial infrastructure is an integral part of the national economy and is a set of fields of science, labor and capital that contribute to the overall development of production by participating in the production process.

Production infrastructure, in turn, is divided into the infrastructures of the fields producing the consumer goods and those producing the produce. It should be understood as a complex of materialtechnical systems that ensure the integrity of commodities in the production process of industrial and coal products. In accordance with the inventory classification, the infrastructure of the production infrastructure should be grouped into the following: production, material resources, natural resources, energy, finished products; production, workforce or operational resources, production finance and information. So, depending on the areas in which they serve, the production infrastructure is externally, internally and in mixed form. These functions are of great importance to the production process itself.

Environmental infrastructure. Areas that serve to the environmental cleanliness, the prevention of environmental pollution, the health of people, fauna and flora are called environmental infrastructure areas.

International Infrastructure. A set of areas that form the national economy as a whole, and which promote the development of international economic integration, are called international infrastructures. This includes international shipping, international transport routes, airports, international trade and market subjects. Compared to other infrastructural areas, international infrastructure is poorly developed, and some are economical

International infrastructures are not included in the study of infrastructure in literature. However, it should be noted that due to global changes in the world, economic integration processes, and intercountry economic relations are developing day by day, international infrastructure is also developing. As time goes by, other infrastructure infrastructures will dominate international infrastructure, and will become a large-scale research facility.

The construction of large international infrastructure facilities has already been completed with the participation of Azerbaijan, and some are under construction. Thus, "Great Silk Road", "BakuTbilisi-Kars" railway, "Baku-Ceyhan-Supsa" pipeline and others. projects can be an example of this.

Institutional infrastructure. In the market economy, public institutions and organizations that are engaged in regulating the economy are called institutional infrastructures. The most common types of market institutional infrastructure are customs, tax, financial, news agencies, audit companies, chamber of commerce, advertising agency.

Military infrastructure. Military infrastructure is a set of areas for the development of the Armed Forces created to protect the sovereignty, territorial integrity, inviolability of the country and its interests. It includes the military bases of the country, the military industry and educational institutions, stationary buildings, armored vehicles, communications and information systems, combat techniques and mechanisms, which provide for the deployment of armed forces and combat operations.

\section{Conclusion}

In order to ensure sustainable economic development in the country, all the infrastructures must be developed in a comprehensive way with innovative development. It may not be helpful to give preference to any of them or ignore others.

\section{References:}

1. Mahmudov M.M., Mahmudova I.M. (2011) Regulation of socio-economic development of regions, Textbook. Baku: University of Economics, 2011, - 369 p.

2. Chernyavsky I.F (1979) Infrastructure of agricultural production: (questions, theories and practices). М .: Экономика, 1979. - 232 p.
3. Vlasov V.V. (1991) Japan: Production Infrastructure. M .: 1991, - $182 \mathrm{p}$.

4. Valiyev T.S. (2000) Infrastructure: essence, classification and significance. Baku: Science, 2000, $-169 \mathrm{p}$.

5. (2010) Economic Theory, Microeconomics-1.2. Textbook / 2011 by the general editorial of the RF Honored Scientist, Doctor of Economics, 


\begin{tabular}{l|lr|ll|ll} 
& ISRA (India) & $=\mathbf{1 . 3 4 4}$ & SIS (USA) & $=\mathbf{0 . 9 1 2}$ & ICV (Poland) & $=\mathbf{6 . 6 3 0}$ \\
Impact Factor: & ISI (Dubai, UAE) $=\mathbf{0 . 8 2 9}$ & PUHL (Russia) $=\mathbf{0 . 2 0 7}$ & PIF (India) & $=\mathbf{1 . 9 4 0}$ \\
& GIIF (Australia) & $=\mathbf{0 . 5 6 4}$ & ESJI (KZ) & $=4.102$ & IBI (India) & $=\mathbf{4 . 2 6 0}$ \\
& JIF & $=1.500$ & SJIF (Morocco) & $=2.031$ & & \\
\hline
\end{tabular}

Professor GP Juravlyova. - 4th edition, revised and supplemented. M :: "Dashkov and Co" publishing and trading corporation, 2010, - 924 p.

6. Gokzhayeva E.B, Ponomareva M.A (2014) Regional economy: infrastructure problems. Rostov on Don: Publishing house "AssistanceXXI century", 2014, - 160 p.

7. Katina P.F., Keating C.B. (2015) Critical infrastructures: a perspective from systems of systems. International Journal of Critical Infrastructures. 2015. 11(4), - p. 316-344.

8. (2017) Ministry of Economy of the Republic of Azerbaijan. Available: http://senaye.gov.az (Accessed: 12.12.2017)
9. Mir-Babayev R., Gulaliyev M., Shikhaliyeva S., Azizova R., Ok N. (2017) The Impact of Cultural Diversity on Innovation Performance: Evidence From Construction Industry of Azerbaijan. Economics and Sociology. 2017. 10(1), - p. 78-93.

10. Perry M. (2010) Controversies in Local Economic Development. Local Economy. 2010. 25(7), - p. 527-534.

11. Verreault-Julien P. (2017) Non-causal understanding with economic models: the case of general equilibrium. Journal of Economic Methodology. 2017. 24(3), - p. 297-317. 